Original Research Paper

\title{
Model Pembelajaran Yang Berorientasi Pada Siswa (Pada Konsep Terapung, Tenggelam dan Melayang)
}

\author{
Syahrial Ayub $^{1 *}$, Agus Ramdani', Ni Nyoman Sri Putu Verawati ${ }^{1}$, Muh. Zuhdi ${ }^{1}$ \\ ${ }^{1}$ Program Studi Pendidikan Fisika, Fakultas Keguruan dan Ilmu Pendidikan, Universitas Mataram.
}

\section{Article history}

Received: May $14^{\text {th }} 2019$

Revised: June $20^{\text {th }} 2019$

Accepted: July $26^{\text {th }} 2019$

*Syahrial Ayub: Program Studi, Pendidikan Fisika, Universitas Mataram,

Indonesia;

Email:

syahrial_ayub@unram.ac.id

\begin{abstract}
Teaching is a teacher's daily job. Nevertheless, it turns out that teaching students about how they should study is not easy. This research is included as Research and Development-also known as $\mathrm{RnD}$ - which aims to give an actual example of how to teach and to floating and simply drowned concept through Curriculum 2013. The result of the research, which is a student-oriented learning design and learning structure which in turn is an implementation of scientific approach, is the output resulted from a long term study, development and experience obtained by the writer team through teaching and training a number of supervisors, school principals, and teachers in various areas of Indonesia. The responses for this teaching model obtained from the teachers have been very positive, whereby $95 \%$ of teachers claimed that they are very interested in the design, and only $5 \%$ claimed that they are mildly interested. This thus indicates that this teaching model can become a model to be referred to in teaching using a scientific approach in Curriculum 2013.
\end{abstract}

Keywords: Student Oriented Model; Floating and Drowned.

Abstrak: Mengajar adalah pekerjaan guru sehari-hari. Namun demikian, mengajar bagaimana peserta didik belajar, ternyata tidaklah mudah. Penelitian ini adalah penelitian dan pengembangan (Research and Development) atau yang biasa disebut dengan $\mathrm{RnD}$, yang bertujuan memberikan contoh nyata bagaimana cara mengajar dan menanamkan konsep terapung dan tenggelam secara sederhana dengan model pembelajaran student oriented. Hasil penelitian berupa desain model pembelajaran student oriented dan struktur pembelajaran yang merupakan penerapan pendekatan saintifik pada kurikulum 2013 merupakan hasil penelitian, pengembangan dan pengalaman tim penulis dalam mengajar dan memberikan pelatihan pada pengawas, kepala sekolah dan bapak ibu guru di berbagai daerah di Indonesia. Respon bapak ibu guru terhadap model pembelajaran ini sangat positif, dimana 95\% menyatakan sangat tertarik dan hanya 5\% yang menyatakan tertarik. Hal ini mengindikasikan bahwa model pembelajaran ini dapat menjadi model acuan dalam mengajar dengan menggunakan pendekatan saintifik di kurikulum 2013.

Kata kunci: Model Student Oriented; Terapung dan Tenggelam.

\section{Pendahuluan}

Terapung, tenggelam dan melayang merupakan salah satu pokok bahasan fisika yang menarik dan menakjubkan. Menarik karena dapat menjelaskan fenomena alam yang terjadi di sekeliling kita dan menakjubkan karena dapat dimanfaatkan untuk kesejahteraan hidup manusia. Pada pokok bahasan ini, ada sesuatu yang menarik untuk dipelajari. Bagaimana cara kerja kapal selam yang dapat mengapung,tenggelam dan melayang di dalam air, bagaimana ikan dapat mengapung, tenggelam dan melayang di air dan bagaimana kapal yang besar dapat mengapung di air. Semua pertanyaan tersebut di atas sungguh menarik untuk 
dipelajari, terlebih bila kita memikirkan bagaimana mengajarkan pokok bahasan ini bagi peserta didik melalui pendekatan saintifik pada kurikulum 2013.

Pendekatan saintifik menggunakan pembelajaran penemuan (Discovery Learning). Discovery Learning merupakan suatu model pembelajaran yang melibatkan secara maksimal seluruh kemampuan peserta didik untuk mencari dan menemukan sesuatu benda, manusia atau peristiwa secara sistematis, kritis, logis, analitis sehingga peserta didik dapat merumuskan sendiri penemuannya dengan penuh percaya diri (Hilmi, 2017). Perubahan tingkah laku peserta didik berkat adanya pengalaman yang diberikan melalui latihan untuk dapat menyelesaikan masalah yang dihadap (Ismayawati, 2016).

Proses benda dapat mengapung dan tenggelam bagi kebanyakan orang merupakan suatu kejadian yang sulit dipahami, apalagi bagi peserta didik yang masih hidup dalam dunia kongkret. Orang bila ditanya mengapa benda dapat terapung dan tenggelam, sebagian besar akan menjawab bahwa, bila massa jenis zat cair lebih besar dari massa jenis benda $\left(\rho_{\text {zatcair }}>\rho_{\text {benda }}\right)$ benda akan terapung dan sebaliknya bila ( $\rho_{\text {benda }}>\rho_{\text {zatcair }}$ ) benda akan tenggelam. Akan tetapi bila mereka diminta untuk menjelaskan dan menghubungkannya dengan kondisi nyata, orang orang tersebut akan mengalami kesulitan. Hal ini disebabkan karena konsep massa jenis merupakan sesuatu yang abstrak. Bagi pembelajaran pada kurikulum 2013 jelas kurang tepat, di sinilah tantangan bagi seorang guru bagaimana membuat peserta didiknya dapat menerima konsep yang diberikan sesuai dengan per-kembangannya.

Tantangan tersebut sangat penting bagi seorang guru mengajarkan fisika lewat keterampilan proses sains. Keterampilan proses sains sebenarnya menjadi dasar pendekatan saintifik di kurikulum 2013. Kurikulum 2013 yang diharapkan dapat diimplementasikan pembelajaran abad 21 yang mencerminkan 4 hal, yaitu berpikir kritis (critical thinking) dan pemecahan masalah (problem solving), kreativitas (creativity) dan inovasi (innovation), komunikasi (communication) (Makhrus, 2019). Salah satu kegiatan yang dapat diambil gutu adalah melakukan percobaan. Percobaan, peserta didik dapat memperoleh pengalaman langsung mengenai hakikat IPA dan berpikir kritis. Berpikir kritis membuat peserta didik mandiri, berdisiplin diri, dimonitor diri, dan memperbaiki proses berpikir sendiri (Ramdhani, 2005). Peserta didik akan lebih mudah mengingat suatu konsep jika ia melihat langsung. Peserta didik bahkan tidak hanya sekedar mengingat tetapi mengerti suatu konsep jika ia melakukan sendiri melalui percobaan. Melalui percobaan, peserta didik dapat menemukan masalah, membuat hipotesis, melakukan percobaan untuk mengumpulkan informasi, mengumpulkan dan menganilisis data, sekaligus mencari jawaban atas masalah yang ditemukan (Nurmayani, 2018).

Masalah yang muncul melalui percobaan merupakan sumber ransangan yang sangat potensial untuk belajar lebih banyak. Dengan percobaan akan terjadi proses belajar fisika yang punya kandungan ilmiah yang berbobot (Abidin, 2014). Masalah fisika akan dipecahkan sendiri lewat percobaan tanpa perlu ceramah teoritis dari gurunya. Melalui percobaan, peserta didik dapat juga dilatih untuk menggunkan metode-metode ilmiah sederhana yang sahih seperti halnya seorang ilmuwan.

Tulisan ini didasarkan pada hasil penelitian, pengalaman dan pengamatan pembelajaran fisika di kelas menggunakan pendekatan saintifik dengan percobaan. Salah satu topik menarik adalah: 1) Bagaimana mengajarkan konsep terapung dan tenggelam dengan student oriented learning; 2) Bagaimana struktur pembelajaran yang berbasis pada peserta didik (student oriented learning structure); 3) Bagaimana aplikasi struktur pembelajaran student oriented dengan pendekatan saintifik?

\section{Metode}

Model pembelajaran student oriented dan struktur yang ditemukan merupakan hasil penelitian dan pengembangan (Research and Development) yang dilakukan peneliti. Penelitian ini dilakukan secara kontinu selama peneliti mengadakan pelatihan peningkatan kualitas pembelajaran IPA pada proyek SEQIP (Science Education Quality Improvement Project) dari Tahun 2000 sampai dengan 2005. Hasil penerapan model yang telah dirancang peneliti di berbagai tempat ini di evaluasi dan direfleksikan pada penerapan berikutnya, sehingga didapatkan model pembelajaran pada saat ini. Jadi model ini merupakan hasil penelitian dan pengembangan yang dilakukan peneliti. Penelitian dan pengembangan atau biasa disebut dengan $\mathrm{RnD}$ digunakan untuk menghasilkan dan menguji keefektifan produk tertentu (Sugiyono, 2013).

Penelitian ini dilakukan dengan 4 tahapan yaitu tahap memutuskan (decide), mendesain (design), pengembangan (develop), dan mengevaluasi (evaluate) (Ivers KS, 2002). Awal 
penelitian ini dilakukan brainstorming, analisis konten dan kajian literatur dalam mengembangkan model pembelajaran. Salah satu hal utama yang diputuskan pada tahap ini adalah konsep fisika yang akan dijadikan model. Pada tahap desain peneliti melakukan perancangan model pembelajaran dengan 3 tahapan, yaitu kegiatan awal, inti, dan penutup yang di sinkronkan dengan pendekatan saintifik. Tahap pengembangan peneliti terus menyempurnakan kekurangan kekurangan pada model yang telah di desain. Berdasarkan hasil evaluasi yang kontinu diharapkan didapatkan model yang terbaik dalam memberikan contoh nyata pembelajaran fisika dengan sederhana dan sesuai dengan pendekatan saintifik.

\section{Hasil dan Pembahasan}

Pendekatan saintifik merekomendasikan 3 pembelajaran, yaitu (1) Discovery Learning, (2) Problem Based Learning dan (3) Project Based Learning. Berbeda dengan metode ceramah, fokus utama dari metode belajar menemukan adalah kegiatan peserta didik secara mandiri (Klinger, 1997). Memang materi dipilih dan disiapkan oleh guru, tetapi para peserta didik yang secara mandiri membahas suatu masalah tertentu atau guru melemparkan suatu pertanyaan tertentu di awal pembelajaran. Diskusi maupun proses kegiatan sebagian besar ditentukan sendiri oleh peserta didik, baik selama pelajaran di kelas maupun di dalam kelompok. Metode ini mempunyai beberapa keunggulan, diantaranya adalah: 1) pengembangan kemandirian dan kegiatan mandiri peserta didik; 2) stimulasi kemampuan merencanakan, mengorganisasi dan melaksanakan kegiatan; 3) pengembangan tanggung jawab terhadap suatu kegiatan, dan 4) pengenalan metode-metode kerja dan berpikir dalam bidang penelitian.

Model discovery learning berpengaruh positif terhadap hasil belajar peserta didik (Huda, 2013). Salah satu keberhasilan utama dari praktek dan teori pengajaran abad ini adalah bahwa peserta didik dianggap sebagai mitra yang bertindak dan berpikir, dan bukan lagi diharapkan untuk menguasai dan menghafal pengetahuan yang tidak ia pahami atau tidak diterangkan secara objektif. Metode belajar menemukan memungkinkan peserta didik untuk mengalami sendiri bagaimana caranya menemukan keterkaitan-keterkaitan baru, dan bagaimana caranya meraih pengetahuan melalui kegiatan mandiri.
Struktur pengajaran memecahkan masalah adalah sebagai berikut (Klinger, 1997) :

Tabel 1: Struktur Pembelajaran Pemecahan Masalah

\begin{tabular}{|c|c|c|}
\hline No & $\begin{array}{l}\text { Langkah } \\
\text { Pengajaran }\end{array}$ & $\begin{array}{l}\text { Tujuan Langkah } \\
\text { Pengajaran }\end{array}$ \\
\hline 1. & Motivasi & $\begin{array}{l}\text { Membangkitkan rasa tertarik } \\
\text { dan keingintahuan peserta } \\
\text { didik terhadap materi } \\
\text { pelajaran yang akan } \\
\text { diajarkan }\end{array}$ \\
\hline 2. & $\begin{array}{l}\text { Penjabaran } \\
\text { masalah }\end{array}$ & $\begin{array}{l}\text { Merumuskan suatu } \\
\text { pertanyaan ilmiah }\end{array}$ \\
\hline 3. & $\begin{array}{l}\text { Penyusunan } \\
\text { opini }\end{array}$ & Perumusan hipotesis \\
\hline 4. & $\begin{array}{l}\text { Perencanaan } \\
\text { dan konstruksi }\end{array}$ & $\begin{array}{l}\text { Persiapan peralatan } \\
\text { percobaan yang akan } \\
\text { digunakan }\end{array}$ \\
\hline 5. & Percobaan & $\begin{array}{l}\text { Perwujudan suatu reaksi } \\
\text { alam }\end{array}$ \\
\hline 6. & Kesimpulan & $\begin{array}{l}\text { Kesimpulan suatu prosedur } \\
\text { pemecahan masalah }\end{array}$ \\
\hline 7. & Abstraksi & Hasil ilmiah yang sah \\
\hline 8 & $\begin{array}{l}\text { Konsolidasi } \\
\text { pengetahuan } \\
\text { melalui aplikasi } \\
\text { dan praktek }\end{array}$ & $\begin{array}{l}\text { Pengetahuan komprehensif } \\
\text { atas suatu gejala alam dan } \\
\text { pengintegrasian hasil } \\
\text { pendidikan }\end{array}$ \\
\hline
\end{tabular}

Model pembelajaran berbasis masalah (Problem Based Learning) adalah penyelesaian masalah terkait materi pembelajaran, bukan bagaimana guru menyampaikan materi pembelajaran (Djamarah, 2005). Model pembelajaran berbasis masalah dengan metode eksperimen menyediakan pengalaman autentik yang mendorong peserta didik untuk belajar aktif (Hamidah, 2018). Pada tahap awal guru mempersiapkan bahan demontrasi untuk menarik minat peserta didik.demonstrasi dirancang untuk memunculkan masalah yang akan menjadi topik pembahasan. Masalah tersebut akan terjawab dengan serangkaian percobaan peserta didik atau demontrasi guru dalam kegiatan inti.

\section{Persiapan Demontrasi}

Guru mempersiapkan demontrasi dengan penyelam kartesian. Penyelam kartesian dibuat dari tabung reaksi yang diletakkan sedemikian rupa sehingga berada pada kondisi terapung di dalam air pada botol, seperti pada Gambar 1 berikut ini: 


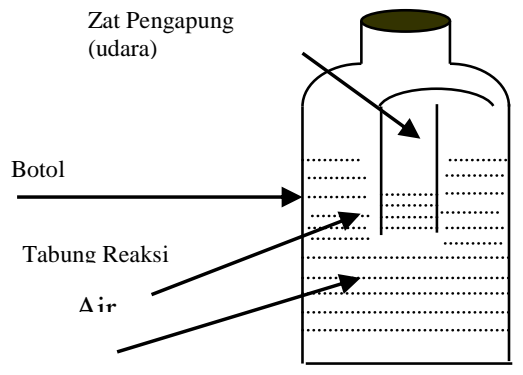

Gambar 1. Penyelam Kartesian

Membuat tabung reaksi agar terapung perlu diperhitungkan perbandingan antara zat pengapung dengan air yang berada di tabung reaksi.

\section{Kegiatan Awal}

Pada kegiatan awal ini, guru berusaha memotivasi peserta didik dengan melakukan demontrasi penyelam kartesian. Guru menanyakan posisi tabung reaksi pada penyelam kartesian, saat ini perjanjian terapung dan tenggelam berdasarkan letak benda diperkenalkan. Kemudian peserta didik diminta untuk menduga apa yang terjadi dengan tabung reaksi bila botol ditekan. Kemungkinan jawaban peserta didik adalah tabung reaksi akan naik seiring dengan naiknya air akibat tekanan dari luar, tabung reaksi akan tetap terapung atau tabung reaksi akan tenggelam. Ternyata setelah guru mencobakan teramati bahwa tabung reaksi tenggelam. Diharapkan dari fenomena ini, akan ada peserta didik yang bertanya: Mengapa tabung reaksi tenggelam bila botol ditekan?

Guru yang bijaksana tentu tidak langsung memberi jawabannya. Bentuk pembelajaran tebakduga-coba untuk memecahkan persoalan di atas akan membuat peserta didik mulai berpikir mengenai konsep terapung dan tenggelam. Intiusi peserta didik merupakan titik awal yang penting dalam langkah selanjutnya.

\section{Kegiatan Inti}

Masalah yang langsung muncul dalam benak peserta didik adalah: bagaimana pencetan (tekanan) yang diberikan pada botol dapat membuat tabung reaksi menjadi tenggelam. Pada tahap ini peserta didik telah mempunyai masalah untuk dipecahkan lewat percobaan. Peserta didik diajak untuk mengungkapkan jawaban sementara (intiusi dan hipotesis) supaya dapat diteliti kebenarannya. Guru tidak perlu memberikan jawaban melalui ceramah atau diskusi antarpeserta didik saja. Saat ini peserta didik mulai memikirkan hubungan pencetan dengan tenggelamnya tabung reaksi. Membuktikan hipotesa mereka tentang terapung dan tenggelam, maka peserta didik dibimbing dengan tiga percobaan sederhana sebagai berikut:

\section{Percobaan 1}

Beberapa jenis benda yang masing-masing mempunyai ukuran berbeda yaitu besar dan kecil di masukkan ke dalam bejana transparan yang berisi air. Berikan kesempatan kepada peserta didik untuk menduga terlebih dahulu apakah benda tersebut akan tenggelam atau terapung jika dimasukkan ke dalam air. Pada gambar 2 diperlihatkan contoh hasil pengamatan.

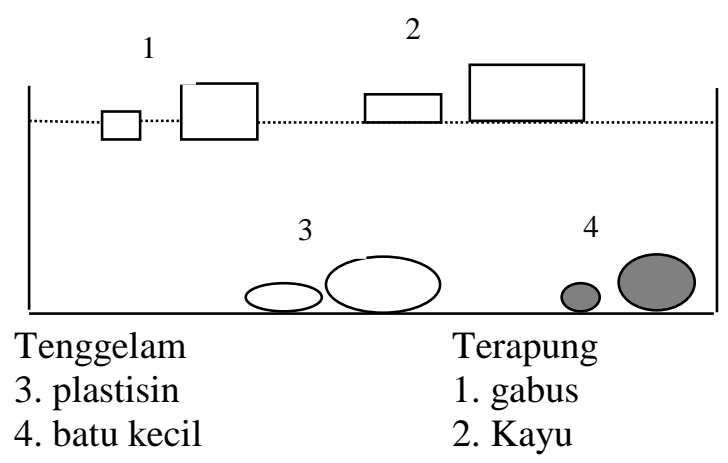

Gambar 2: Hasil pengamatan percobaan 1

Setelah peserta didik mengamati, guru dapat membimbing diskusi peserta didik berdasarkan hasil percobaan sederhana ini untuk mencapai kesimpulan yang disepakati bersama oleh seluruh kelas. Percobaan ini akan memberi kesimpulan bahwa terapung atau tenggelamnya suatu benda tidak tergantung dari ukuran benda tetapi dari jenis benda.

\section{Percobaan 2}

Membuat bola-bola plastisin dengan ukuran yang berbeda-beda. Bola plastisin no.3 yang dipersiapkan sebelum masuk kelas dibuat dalam bentuk yang berbeda.

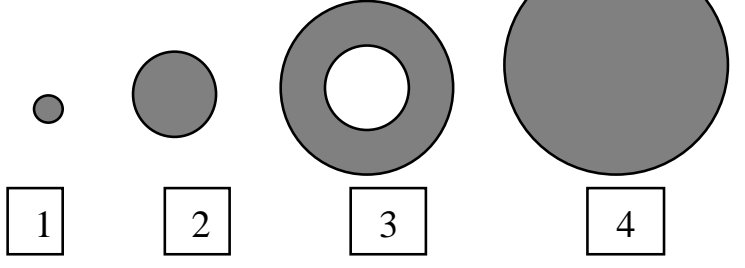

Gambar 3: Bola-bola plastisin

Bola-bola plastisin dimasukkan satu persatu ke dalam air, dimulai dari yang paling kecil. Sebelum setiap bola dimasukkan, peserta diminta menduga apakah bola tersebut akan terapung atau tenggelam. Pada gambar 4 diperlihatkan contoh hasil pengamatan. 

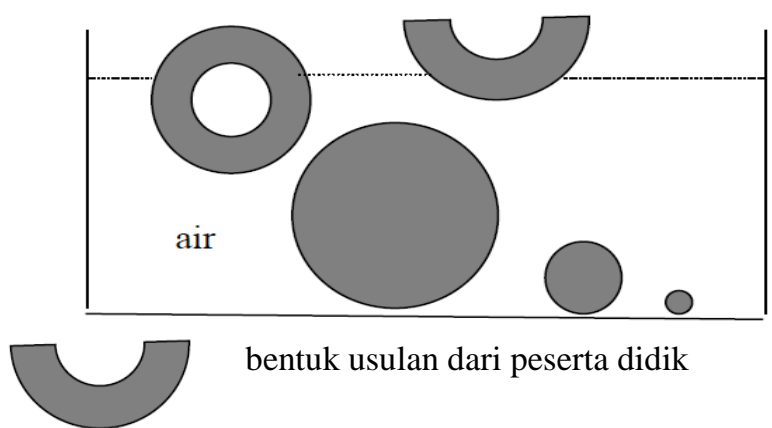

bentuk usulan dari peserta didik

Gambar 4 : Hasil pengamatan percobaan 2

Setelah peserta didik mengamati, guru dapat membimbing diskusi peserta didik berdasarkan hasil percobaan sederhana ini untuk mencapai kesimpulan yang disepakati bersama oleh seluruh kelas. Percobaan ini akan memberi kesimpulan bahwa terapung atau tenggelam suatu benda, tidak hanya tergantung pada jenis benda tetapi juga tergantung pada bentuknya.

\section{Percobaan 3}

Percobaan ini adalah menenggelamkan pipet ke dalam air, seperti pada gambar 5 di bawah ini:

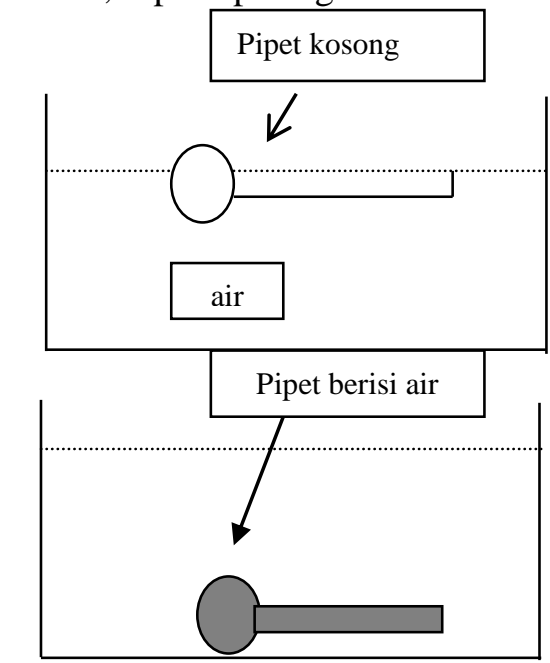

Gambar 5: Hasil pengamamatan percobaan 3

Setelah peserta didik mengamati, guru dapat membimbing diskusi peserta didik berdasarkan hasil percobaan sederhana ini untuk mencapai kesimpulan yang disepakati bersama oleh seluruh kelas. Percobaan ini akan memberikan kesimpulan bahwa: terapung dan tenggelamnya suatu benda tergantung pada ukuran zat pengapung. Berdasarkan kesimpulan percobaan 1, 2 dan 3, guru kembali membahas permasalahan pertama. Diharapkan peserta didik dapat menemukan tenggelamnya tabung reaksi akibat semangkin berkurang ukuran zat pengapung.

\section{Kegiatan Penutup}

Dalam kegiatan pemantapan ada beberapa hal yang harus dibahas oleh guru. Satu penerapan yang paling penting adalah bagaimana kapal selam dapat mengapung dan tenggelam di air?, bagaimana ikan dapat mengapung dan tenggelam di air?. Hal ini merupakan contoh yang menarik bila dihubungkan dengan topik terapung dan tenggelam.

Bila kita kaitkan alur pembelajaran ini dengan pendekatan saintifik di kurikulum 2013 sangat sesuai dengan tahapan-tahapannya. Ada 6 tahapan pendekatan saintifik, yaitu: (1) mengamati, (2) menanya, (3) mengumpulkan informasi, (4) mengasosiasi, (5) menyimpulkan, mengkomunikasikan (Ramdani, 2019). Demo penyelam kartesian terbukti mampu menarik perhatian peserta didik. Setiap peserta didik berusaha menjelaskan fenomena tersebut dengan logikanya sendiri. Ini termasuk tahap mengamati pada pendekatan saintifik dikurikulum 2013. Untuk meneliti setiap pendapat, peserta didik diajak melakukan serangkaian percobaan dengan terlebih dahulu merumuskan masalah sebagai berikut: mengapa tabung reaksi tenggelam bila botol ditekan?

Permasalahan ini sebaiknya ditemukan langsung oleh peserta didik dengan langsung bertanya (tahap menanya). Baru setelah itu kita masuk ke tahap mengumpulkan informasi, mengasosiasi dan menyimpulkan. Untuk menjawab permasalahan tersebut guru mengajak peserta didik untuk melakukan beberapa kegiatan. Pada percobaan 1 dengan memasukkan berbagai jenis benda ke dalam air dengan setiap jenisnya mempunyai ukuran yang berbeda, mempunyai tujuan untuk mengiring peserta didik pada suatu kesimpulan bahwa terapung atau tenggelamnya suatu benda tergantung pada jenis benda tidak tergantung pada ukurannya.

Percobaan 2, ingin menginformasikan kepada peserta didik melalui percobaan bahwa di samping tergantung pada jenis benda, terapung/tenggelam juga tergantung pada bentuk benda. Buktinya jenis plastisin yang semula tenggelam dapat menjadi terapung bila diubah bentuknya.

Percobaan 3, disamping jenis benda, bentuk benda, ukuran zat pengapung juga mempengaruhi terapung/tenggelamnya suatu benda. Diharapkan dari 3 percobaan yang telah dilakukan ini, peserta didik diharapkan mampu menjawab sendiri permasalahan utama. Bila kita amati pada saat botol ditekan, ukuran zat pengapung pada tabung reaksi berkurang dengan naiknya permukaan air dalam 
tabung reaksi. Terakhir adalah kegiatan mengkomunikasikan yaitu antara lain menjelaskan aplikasinya. Konsep inilah yang diterapkan pada kapal selam. Di kapal selam ada ruangan khusus untuk dapat mengubah ukuran zat pengapungnya dengan cara memasukkan dan mengeluarkan air dari ruangan itu. Demikian juga ikan, pada setiap ikan mempunyai gelembung udara di perutnya yang berfungsi sebagai zat pengapung. Tentu dengan mengkontraksikan otot-ototnya ikan dapat mengubah ukuran zat pengapungnya sehingga ikan dapat tenggelam dan terapung di air. Berdasarkan hasil ini, peneliti menemukan struktur pembelajaran student oriented adalah sebagai berikut:

Tabel 2: Struktur Pembelajaran Student Oriented

\begin{tabular}{lll}
\hline Tahap Pokok & Tahap Pengajaran & Alternatif Kegiatan yang dapat Dilakukan \\
\hline 1. Kegiatan Awal & Pendahuluan & - Demonstrasi sesuatu yang dibawa oleh guru \\
& & - Cerita / kejadian \\
& - Review atau melanjutkan pelajaran terdahulu yang belum \\
& & lengkap \\
& - Mengamati/membahas penerapan tekhnis dalam lingkungan \\
& Pengetahuan Awal Siswa & - Menyanyi (berhubungan dengan materi yang akan diajarkan) \\
& & Mengampaikan tujuan pembelajaran \\
&
\end{tabular}

2. Kegiatan Inti

Perumusan pertanyaan/
permasalahan tentang
topik pembelajaran
Kegiatan

Pengamatan Jawaban pertanyaan pemecahan masalah

3. Kegiatan Pemantapan
Penjelasan Oleh Guru (Bila diperlukan)
- Merumuskan pertanyaan atau permasalahan tentang topik pembelajaran

- Melaksanakan percobaan

- Permainan/simulasi

- Mengumpulkan bahan/bahan untuk dibandingkan, diklasifikasikan.

- Periksa cara kerja alat teknis

- Melakukan pengamatan sebanyak mungkin

- Penjelasan oleh siswa (tebak-duga-diskusi)

- Landasan pemikiran

- Perumusan masalah

- Penerapan (sangat baik bila berhubungan dengan lingkungan siswa)

- Menjawab pertanyaan

- Membuat ringkasan

- Pekerjaaan rumah
Struktur ini masih mungkin untuk dikembangkan lagi sesuai dengan materi yang diajarkan.

\section{Kesimpulan}

Metode belajar dengan pendekatan saintifik sangat cocok dalam pembelajaran fisika. Terbukti bahwa pembelajaran ini membuat peserta didik lebih memahami konsep yang dipelajarinya, lebih antusias dan terlibat aktif dalam mengikuti pembelajaran tersebut. Demikian juga pada gurunya, metode ini menuntut banyak kemampuan yang harus dimiliki oleh seorang guru, misalnya guru harus menguasai materi, terbiasa berpikir logis seperti seorang ilmuwan, sikap mental yang terbuka (demokratis), cepat tanggap membaca pikiran orang lain, dan ingin selalu berkembang. Anggapan guru bahwa pendekatan saintifik membatasi kreatifitas guru menjadi terpatahkan karena ternyata pendekatan saintifik pada kurikulum 2013 memberikan kewenangan lebih buat guru dalam mengoptimalkan kreatifitas dan inovasinya.

\section{Daftar Pustaka}

Abidin. Y. 2014. Desain Sistem Pembelajaran dalam Konteks Kurikulum 2013. Bandung. PT Refika Adiatama

Djamarah. 2005. Guru dan Anak Didik Dalam Interaksi Edukatif, Suatu Pendekatan Teoritis Psikologis. Jakarta. Rineka Cipta.

Hamidah, Gunawan, \& Taufik, M. 2018. Pengaruh Model Discovery Learning Berbantuan Media Phet terhadap Hasil Belajar Fisika Peserta Didik Kelas XI SMA N 1 Kediri 
Tahun Ajaran 2017/2018. Jurnal Pendidikan Fisika dan Teknologi. 4(1).

Hilmi, N. 2017. Pengaruh Model Pembelajaran Discovery dengan Pendekatan Saintifik dan Keterampilan Proses terhadap Hasil Belajar Peserta Didik. Jurnal Penelitian Pendidikan IPA, 3(2), 1-7

Huda. M. 2013. Model Model Pengajaran dan Pembelajaran Isu-Isu Metodis dan Pragmatis. Yogyakarta. Pustaka Pelajar

Ismayawati, B. 2016. Pengaruh Model Pembelajaran Berbasis Masalah (PBM) dalam Setting Pembelajaran Kooperatif Tipe TGT dan GI terhadap Kemampuan Berpikir Kritis dan Hasil Belajar Kimia Peserta Didik SMA N 1 Aikmel. Jurnal Penelitian Pendidikan IPA, 2(1), 54-65

Ivers, K.S., \& Barron, A.E. 2002. Multimedia Project in Education: Designing Producing and Assessing. USA. Libraries Unlimited

Klinger, W. 1997. Survei Metode Pengajaran dalam Ilmu Pengetahuan Alam. Erziehungswiss. Fakultat der Universtat, Erlangen-Nurnbe

Makhrus, M. 2019. Analisis Rencana Pelaksanaan Pembelajaran (RPP) terhadap Kesiapan Guru sebagai "Role Model" Keterampilan abad 21 pada Pembelajaran IPA SMP. Jurnal Penelitian Pendidikan IPA, 5(1), 66108

Nurmayani, L., 2018. Pengaruh Model Pembelajaran Inkuiri Terbimbing Terhadap Hasil Belajar Peserta Didik. Jurnal Penelitian Pendidikan IPA, 4(2), 23-28

Ramdani, A. 2019. Pengembangan Alat Evaluasi Pembelajaran IPA Yang Mendukung Keterampilan Abad 21. Jurnal Penelitian Pendidikan IPA, 5(1), 98-108

Ramdani, A. 2005. Optimalisasi Pembelajaran Fisika dengan Penggunaan Kit IPA di SMPN 6 Mataram. Mataram. Unram Press.

Sugiyono. 2013. Metode Penelitian Kuantitif Kualitatif dan $R \& D$. Bandung. Alfabeta 